\title{
Antioxidant, Antimicrobial, and Molecular Docking Studies of Novel 1, 4- naphthoquinone Derivatives
}

Nadia Elkanzi ( $\square$ kanzi20@yahoo.com)

Aswan University https://orcid.org/0000-0002-1687-1834

Hajer Hrichi

Al Jouf University: Al-Jouf University

Rania B. Bakr

Al Jouf University: Al-Jouf University

\section{Research Article}

Keywords: Heterocycles, 1,4-naphthoquinone, antimicrobial, antioxidant, molecular docking

Posted Date: March 6th, 2021

DOI: https://doi.org/10.21203/rs.3.rs-273544/v1

License: () (i) This work is licensed under a Creative Commons Attribution 4.0 International License. Read Full License 


\begin{abstract}
The synthesis of novel 1,4-naphthoquinone derivatives has attracted prominent interest in the field of medicinal chemistry since these compounds exhibit potent pharmacological activity as antibacterial, antioxidant, antifungal, and anticancer. Herein, a series of novel 1,4-naphthoquinone derivatives 4-7, 8a-c, and 9a-d containing heterocyclic moieties were synthesized in good yields and characterized by spectral and elemental analyses. All the new synthesized compounds were subjected to in-vitro antimicrobial testing against gram-positive, gram-negative, and fungal strains by calculating the average of the zone of inhibition. The antimicrobial results showed that compounds $8 b, 9 b$, and $9 c$ displayed the highest efficacy against both bacterial and fungal strains. Further studies have been conducted to estimate the antioxidant activity of the compounds using DPPH scavenging assay. The obtained results revealed that compounds 9d, 9a, 9b, 8c, and $\mathbf{6}$ exhibited the highest radical scavenging activity. Docking studies of the most active antimicrobial compounds within GLN- $6-$ $\mathrm{P}$, recorded good scores with several binding interactions with the active site.
\end{abstract}

\title{
Introduction
}

The new approaches in synthetic procedures that enable fast access to a broad variety of functionalized heterocyclic compounds are extremely substantial in modern drug design since more than $85 \%$ of all pharmacologically active molecules contain a heterocycle [1]. It was demonstrated that the size and type of the substituted heterocycle scaffolds affect strongly their physicochemical and biological properties [2, 3]. In recent years, substantial research has been oriented towards the combination of more than two heterocycles molecules bearing different sites of actions to obtain remarkable biological activities [4].

Chalcone (1,3-diphenyl-2-propen-1-ones) is one of the privileged structures that has been widely used as an effective scaffold in medicinal chemistry for drug discovery due to its broad therapeutic applications [5-7]. These compounds are considered as the precursors of flavonoids [8,9] and a considerable number of natural and synthetic chalcones have been found to be associated with diverse biological activities, including antibacterial [10, 11] antimalarial [12], antiinflammatory [13], antioxidant [14], anticancer [15, 16], etc. The distinct a, $\beta$-unsaturated ketone structure of chalcones is responsible for the broad-spectrum of biological activities. Consequently, there is a continuous urge for the development of new chalcone derivatives that are not susceptible to the existing resistance mechanisms [17]. Naphthoquinones, the most commonly occurring type of quinones, have attracted great attention from pharmacologists, and they are used as intermediates in the preparation of drugs. Similarly to benzoquinone and anthraquinone, naphthoquinones have a conjugated electron system responsible for transporting electron to other molecules [18].

Synthetic and naturally occurring 1,4-naphthoquinone are privileged structures due to their redox and acid-base properties [19]. Besides, the synthesis of novel derivatives of 1,4-naphthoquinone is of particular interest since these compounds exhibit strong action as antimicrobial [20,21], anti-inflammatory [22, 23], antiseptic [24], anti-cancer [25, 26], antimalarial [27] and antioxidant [28] activities. Previous relationship-structure activity studies from quinoid derivatives revealed that the presence and the position of nitrogen atoms substituted in the quinone nucleus are among the critical factors that improve their biological properties. Accordingly, numerous protocols to synthesize these compounds have been reported [29]. Moreover, many studies related to Schiff bases have been reported so far because of their use in many fields such as medical, analytical and biological chemistry [30]. Schiff bases bearing heterocycles exhibit a broad spectrum of pharmacological activities including anti-inflammatory [31], antimicrobial [32], anticancer [33], antitubercular [34], analgesic and antiulcerogenic [35], etc. Furthermore, in synthetic medicinal chemistry, heterocyclic compounds bearing the pyrimidine ring have been found to denote potent pharmacological activity involved in a wide range of biological studies [36].

Owing to the strong demand for the preparation of new scaffolds bearing strong antimicrobial and antioxidant activities by simple chemical procedures, it becomes critical to explore new combinations of bioactive heterocycles. As an extension to our studies [37-39] aiming to synthesize novel heterocyclic ring systems having potent pharmacological activity, we describe herein the design, characterization, antimicrobial, and antioxidant activities of new Schiff bases, chalcones and pyrimidines derivatives bearing 1,4-naphthoquinone moiety. Molecular docking studies were realized to predict accurately the type of interactions and the binding affinity between the docked synthesized ligands and the active site of the target protein to form a stable complex.

\section{Material And Methods General}

All the reagents and solvents reported in present study were purchased from Sigma-Aldrich (Bayouni Trading Co. Ltd., Al-Khobar, Saudi Arabia) with high grade of purity and used without any further purification. The progress of all reactions was examined using thin-layer chromatography (TLC) on silica gel pre-coated F254Merck plates (Darmstadt, Germany) and the spots were detected by exposure to UV light at $250 \mathrm{~nm}$. All melting points are uncorrected and were recorded on open capillary tubes using a Gallenkamp melting point apparatus. The FTIR measurements of the reported compounds were recorded on Shimadzu model FT-IR-8400S spectrophotometer using potassium bromide disks. The ${ }^{1} \mathrm{H},{ }^{13} \mathrm{C}-\mathrm{NMR}$ spectra were run on a Varian MercuryVXR-300 NMR spectrometer (Palo Alto, CA) at 400 and $125 \mathrm{MHz}$ in dimethyl sulfoxide-d 6. Chemical shifts were reported in ppm ( $\delta$ ) with reference to the internal standard TMS. Mass spectra were obtained at $70 \mathrm{eV}$ on a shimadzu GCMS-QP 1000EX spectrometer. Elemental analyses $(\mathrm{C}, \mathrm{H}$, and $\mathrm{N})$ of the synthesized compounds were realized on $\mathrm{CE}$ 440 Elemental Analyzer- Automatic Injector (Exeter Analytical, Inc., USA) at the Micro analytical Center of Cairo University. The physical data, elemental analysis, mass spectra, and IR spectra results of all the newly synthesized compounds are presented in Table 1.

\section{Chemistry}

\section{Procedure for the synthesis of 5-((3-acetyl-1,4-dioxo-1,4-dihydronaphthalen-2- yl)diazenyl)-2-hydroxybenzaldehyde (3)}

Compound (1) (2-acetyl-3-aminonaphthalene-1, 4-dione(1)) and diazonium salt (2) were synthesized according to previous methods [40-42]. 
Compound (1) $(2.15 \mathrm{~g}, 0.01 \mathrm{~mol})$ was subjected to a diazotation reaction, it was dissolved in a round bottom flask with $16 \mathrm{~mL}$ of $85 \%$ phosphoric acid and heated under stirring. Subsequently, the obtained solution was cooled to $0^{\circ} \mathrm{C}$ in an ice bath and then was concentrated in $8 \mathrm{~mL}$ nitric acid. A solution of sodium nitrite $(3.74 \mathrm{mmol})$ in $4 \mathrm{~mL}$ of water was added to the mixture under vigorous stirring at a temperature below $5^{\circ} \mathrm{C}$ for 10 minutes. Afterward, salicylaldehyde $(0.374 \mathrm{mmol})$ in $1 \mathrm{~mL}$ water was added dropwise to the mixture under magnetic stirring.

The resulting red solid was filtered, washed several times with water, and then dissolved in $30 \mathrm{~mL} 10 \% \mathrm{NaOH}$. The solution was filtered; the crude product was precipitated during the neutralization with $10 \% \mathrm{HCl}$, then filtered and washed with water several times.

${ }^{1} \mathrm{H}$ NMR (400 MHz, DMSO- $\left.d_{6}, \delta, \mathrm{ppm}\right): 10.41\left(\mathrm{~s}, 1 \mathrm{H}\right.$, aldehyde -H), 7.02-8.8.53 (m, 7H, Ar-H), $5.43(\mathrm{~s}, 1 \mathrm{H}, \mathrm{O}-\mathrm{H}), 2.55\left(\mathrm{~s}, 3 \mathrm{H}, \mathrm{CH}_{3}\right) .{ }^{13} \mathrm{C}-\mathrm{NMR}\left(\mathrm{DMSO}-\mathrm{d}_{6}\right) \delta=29.63$ $\left(\mathrm{CH}_{3}\right), 122.37,126.72,132.23,135.21,116.57,121.95,118.41,129.93,136.22,144.46,152.33(\mathrm{C}=\mathrm{C}), 161.94(\mathrm{C}-\mathrm{OH}), 173.22,177.61,194.63,198.74(4 \mathrm{C}=0)$ ppm.

\section{General procedure for the synthesis of Schiff bases (4-6)}

Compound $3(3.48 \mathrm{~g}, 0.01 \mathrm{mmol})$ was reacted with an aromatic amine and dissolved separately in a minimum amount of ethanol, then mixed together and followed by addition of three drop of glacial acetic acid. Then, the solution was refluxed for $6-8 \mathrm{~h}$ then cooled to room temperature and poured in to ice-cold water. The resulting product was recrystallized from ethanol.

\section{Synthesis of 2-acetyl-3-((4-hydroxy-3-((E)-(pyridin-2-ylimino)methyl) phenyl)diazenyl) naphthalene-1,4-dione (4)}

${ }^{1} \mathrm{H}$ NMR $\left(400 \mathrm{MHz}, \mathrm{DMSO}-\mathrm{d}_{6}, \delta, \mathrm{ppm}\right): 7.02-8.8 .53(\mathrm{~m}, 12 \mathrm{H}, \mathrm{Ar}-\mathrm{H}, \mathrm{CH}=\mathrm{N}), 5.42(\mathrm{~s}, 1 \mathrm{H}, \mathrm{O}-\mathrm{H}), 2.54\left(\mathrm{~s}, 3 \mathrm{H}, \mathrm{CH}_{3}\right) .{ }^{13} \mathrm{C}-\mathrm{NMR}\left(\mathrm{DMSO}^{\left.-\mathrm{d}_{6}\right)} \delta=29.63(\mathrm{CH}), 122.37\right.$, $126.72,132.23,135.21,116.57,121.95,117.98,129.93,136.22,144.46,152.33,118.86,119.74,137.52,145.31(\mathrm{C}=\mathrm{C}), 161.94(\mathrm{C}-\mathrm{OH}), 156.94,161.89(2 \mathrm{C}=\mathrm{N})$, $173.22,177.61,198.74(3 \mathrm{C}=0) \mathrm{ppm}$.

\section{Synthesis of 2-acetyl-3-((4-hydroxy-3-((E)-(pyrimidin-2-ylimino) methyl) phenyl) diazenyl) naphthalene-1,4-dione (5)}

${ }^{1} \mathrm{H}$ NMR $\left(400 \mathrm{MHz}, \mathrm{DMSO}-d_{6}, \delta, \mathrm{ppm}\right): 7.02-8.8 .53(\mathrm{~m}, 11 \mathrm{H}, \mathrm{Ar}-\mathrm{H}, \mathrm{CH}=\mathrm{N}), 5.52(\mathrm{~s}, 1 \mathrm{H}, \mathrm{O}-\mathrm{H}), 2.54\left(\mathrm{~s}, 3 \mathrm{H}, \mathrm{CH}_{3}\right) .{ }^{13} \mathrm{C}-\mathrm{NMR}\left(\mathrm{DMSO}^{\left.-\mathrm{d}_{6}\right)} \delta=29.63\left(\mathrm{CH}_{3}\right), 122.37\right.$, $126.72,132.23,135.21,116.57,121.95,117.98,129.93,136.22,144.46,152.33,118.86,114.71,158.62(C=C), 161.94(C-0 H), 158.89,160.88,167.51(3 \mathrm{C}=\mathrm{N})$, $173.22,177.61,198.74(3 \mathrm{C}=0) \mathrm{ppm}$.

Synthesis of 2-acetyl-3-((3-((E)-((1,5-dimethyl-3-oxo-2-phenyl-2,3-dihydro-1H-pyrazol-4 yl)imino) methyl )-4-hydroxyphenyl)diazenyl)naphthalene-1,4-dione (6)

${ }^{1} \mathrm{H}$ NMR (400 MHz, DMSO-d $\left.d_{6}, \delta, \mathrm{ppm}\right): 7.02-8.8 .53(\mathrm{~m}, 13 \mathrm{H}, \mathrm{Ar}-\mathrm{H}, \mathrm{CH}=\mathrm{N}), 5.54(\mathrm{~s}, 1 \mathrm{H}, \mathrm{O}-\mathrm{H}), 3.11\left(\mathrm{~s}, 3 \mathrm{H}, \mathrm{CH}_{3}\right), 2.44\left(\mathrm{~s}, 3 \mathrm{H}, \mathrm{CH}_{3}\right), 2.54\left(\mathrm{~s}, 3 \mathrm{H}, \mathrm{CH}_{3}\right) .{ }^{13} \mathrm{C}-\mathrm{NMR}$ $\left(\right.$ DMSO $\left.-\mathrm{d}_{6}\right) \delta=14.79,29.63,35.21\left(3 \mathrm{CH}_{3}\right), 122.37,126.72,132.23,135.21,116.57,121.95,117.98,129.93,136.22,144.46,152.33,110.35,150.66,122.99$, $123.98,129.41,134.22$, (C = C), $161.94(\mathrm{C}-\mathrm{OH}), 163.94(\mathrm{C}=\mathrm{N}), 160.96,173.22,177.61,198.74$ (4 C = 0) ppm.

\section{Synthesis of 2-acetyl-3-((3-acetyl-2-oxo-2H-chromen-6-yl)diazenyl)naphthalene-1,4-dione (7)}

Compound $3(0.01 \mathrm{~mol})$ was reacted with ethyl acetoacetate $(0.01 \mathrm{~mol})$ in $20 \mathrm{ml}$ of dry chloroform in the presence of few drops of piperidine as catalyst, the mixture was heated under reflux for $4 \mathrm{~h}$. The reaction mixture was cooled to room temperature and the obtained solid was filtered, washed with cold water, dried and recrystallized from methanol.

${ }^{1} \mathrm{H}$ NMR (400 MHz, DMSO- $\left.d_{6}, \delta, \mathrm{ppm}\right): 7.02-8.8 .53(\mathrm{~m}, 17 \mathrm{H}, \mathrm{Ar}-\mathrm{H}), 3.11\left(\mathrm{~s}, 3 \mathrm{H}, \mathrm{CH}_{3}\right), 2.25\left(\mathrm{~s}, 3 \mathrm{H}\right.$, acetyl-H). ${ }^{13} \mathrm{C}-\mathrm{NMR}\left(\mathrm{DMSO}-\mathrm{d}_{6}\right) \delta=29.63,29.81,126.72$, $132.23,135.21,116.57,144.46,152.33,131.56,137.88,122.31,117.61,125.42,125.19,129.52,159.51$ (C= C), 173.22, 177.61, 159.62, 198.74, $198.81(5 \mathrm{C}=$ 0) $\mathrm{ppm}$.

\section{Procedure for the synthesis of Chalcone derivatives (8a-c)}

To an equimolar mixture of compound $7(4.14 \mathrm{~g}, 0.01 \mathrm{~mol})$ and aromatic aldehydes $(0.01 \mathrm{~mol})$ in ethanol $(30 \mathrm{ml})$ was added an aqueous solution of $\mathrm{NaOH}$ (40\%) under magnetic stirring. The reaction mixture was kept overnight at room temperature and the resulting precipitate was filtered, washed with diethyl ether and recrystallized from ethanol. The results obtained from TLC showed that the reaction was completed using (benzene ethanol 2:1).

\section{Synthesis of 2-acetyl-3-((2-oxo-3-(3-phenylacryloyl)-2H-chromen-6-yl)diazenyl)} naphthalene - 1,4-dione (8a)

${ }^{1} \mathrm{H}$ NMR (400 MHz, DMSO- $\left.d_{6}, \delta, \mathrm{ppm}\right): 7.02-8.8 .53(\mathrm{~m}, 13 \mathrm{H}, \mathrm{Ar}-\mathrm{H}),, 6.96(\mathrm{~d}, 1 \mathrm{H}, \mathrm{CH}=), 6.75(\mathrm{~d}, 1 \mathrm{H}, \mathrm{O}=\mathrm{C}-\mathrm{CH}), 3.11(\mathrm{~s}, 3 \mathrm{H}, \mathrm{CH}) .{ }^{13} \mathrm{C}-\mathrm{NMR}\left(\mathrm{DMSO}-\mathrm{d}_{6}\right) \delta=29.63$, $126.72,132.23,135.21,116.57,144.46,152.33,131.56,137.88,122.31,117.61,125.42,125.19,129.52,159.51,127.97,128.66,128.75,135.31(\mathrm{C}=\mathrm{C}), 125.81$, $142.32(\mathrm{CH}=\mathrm{CH}), 173.22,177.61,159.62,183.86,198.74(5 \mathrm{C}=0) \mathrm{ppm}$.

Synthesis of 2-acetyl-3-((3-(3-(4-chlorophenyl)acryloyl)-2-oxo-2H-chromen-6-yl)diazenyl) naphthalene-1,4-dione (8b) 
${ }^{1} \mathrm{H}$ NMR (400 MHz, DMSO- $\left.d_{6}, \delta, \mathrm{ppm}\right): 7.02-8.8 .53(\mathrm{~m}, 12 \mathrm{H}, \mathrm{Ar}-\mathrm{H}),, 6.98(\mathrm{~d}, 1 \mathrm{H}, \mathrm{CH}=), 6.79(\mathrm{~d}, 1 \mathrm{H}, \mathrm{O}=\mathrm{C}-\mathrm{CH}), 3.11(\mathrm{~s}, 3 \mathrm{H}, \mathrm{CH}) .{ }^{13} \mathrm{C}-\mathrm{NMR}\left(\mathrm{DMSO}-\mathrm{d}_{6}\right) \delta=29.63$, $126.72,132.23,135.21,116.57,144.46,152.33,131.56,137.88,122.31,117.61,125.42,125.19,129.52,159.51,128.69,129.46,133.46,133.58(C=C), 125.81$, $142.32(\mathrm{CH}=\mathrm{CH}), 173.22,177.61,159.62,183.86,198.74(5 \mathrm{C}=0) \mathrm{ppm}$.

\section{Synthesis of 2-acetyl-3-((3-(3-(4-hydroxyphenyl)acryloyl)-2-oxo-2H-chromen-6-yl)diazenyl) naphthalene-1,4-dione (8c)}

${ }^{1} \mathrm{H}$ NMR (400 MHz, DMSO- $\left.d_{6}, \delta, \mathrm{ppm}\right): 7.02-8.8 .53(\mathrm{~m}, 12 \mathrm{H}, \mathrm{Ar}-\mathrm{H}),, 5.56(\mathrm{~s}, 1 \mathrm{H}, \mathrm{OH}), 6.98(\mathrm{~d}, 1 \mathrm{H}, \mathrm{CH}=), 6.79(\mathrm{~d}, 1 \mathrm{H}, \mathrm{O}=\mathrm{C}-\mathrm{CH}), 3.11(\mathrm{~s}, 3 \mathrm{H}, \mathrm{CH}) .{ }^{13} \mathrm{C}-\mathrm{NMR}$ $\left(\right.$ DMSO $\left.-d_{6}\right) \delta=29.63,126.72,132.23,135.21,116.57,144.46,152.33,131.56,137.88,122.31,117.61,125.42,125.19,129.52,159.51,116.12,127.95,130.69$, $157.92(\mathrm{C}=\mathrm{C}), 125.81,142.32(\mathrm{CH}=\mathrm{CH}), 173.22,177.61,159.62,183.86,198.74(5 \mathrm{C}=0) \mathrm{ppm}$.

Synthesis of Chalcone derivatives (9a-d)

To an equimolar mixture of compound $\mathbf{3}(3.48 \mathrm{~g}, 0.01 \mathrm{~mol})$ and p-substituted acetophenone $(0.01 \mathrm{~mol})$ in ethanol (30 ml) was added an aqueous solution of $\mathrm{NaOH}(40 \%)$. The reaction mixture was kept under stirring overnight at room temperature. Then, the resulting precipitate was filtered, washed with diethyl ether and recrystallized from ethanol. TLC results showed that the reaction was completed using (benzene ethanol 2:1).

\section{Synthesis of 2-acetyl-3-((3-((E)-3-(4-aminophenyl)-3-oxoprop-1-en-1-yl)-4-hydroxy phenyl )diazenyl ) naphthalene-1,4-dione (9a)}

${ }^{1} \mathrm{H}$ NMR $\left(400 \mathrm{MHz}, \mathrm{DMSO}-\mathrm{d}_{6}, \delta, \mathrm{ppm}\right): 9.25\left(\mathrm{~s}, 2 \mathrm{H}, \mathrm{NH}_{2}\right), 7.02-8.8 .53(\mathrm{~m}, 11 \mathrm{H}, \mathrm{Ar}-\mathrm{H}),, 5.56(\mathrm{~s}, 1 \mathrm{H}, \mathrm{OH}), 6.98(\mathrm{~d}, 1 \mathrm{H}, \mathrm{CH}=), 6.79(\mathrm{~d}, 1 \mathrm{H}, \mathrm{O}=\mathrm{C}-\mathrm{CH}), 3.11(\mathrm{~s}, 3 \mathrm{H}$, $\mathrm{CH}_{3}$ ). ${ }^{13} \mathrm{C}-\mathrm{NMR}\left(\mathrm{DMSO}-\mathrm{d}_{6}\right.$ ) $\delta=29.63,126.72,132.23,135.21,116.57,144.46,152.33,121.53,115.94,116.71,126.51,129.62,157.23,127.97,114.88,132.31$, $154.45(\mathrm{C}=\mathrm{C}), 122.37,141.63(\mathrm{CH}=\mathrm{CH}), 173.22,177.61,189.82,198.74(4 \mathrm{C}=0) \mathrm{ppm}$.

\section{Synthesis of 2-acetyl-3-((3-((E)-3-(4-chlorophenyl)-3-oxoprop-1-en-1-yl)-4-hydroxyphenyl) diazenyl) naphthalene-1, 4-dione (9b)}

${ }^{1} \mathrm{H}$ NMR (400 MHz, DMSO- $\left.d_{6}, \delta, \mathrm{ppm}\right): 7.02-8.8 .53(\mathrm{~m}, 11 \mathrm{H}, \mathrm{Ar}-\mathrm{H}),, 5.37(\mathrm{~s}, 1 \mathrm{H}, \mathrm{OH}), 6.99(\mathrm{~d}, 1 \mathrm{H}, \mathrm{CH}=), 6.86(\mathrm{~d}, 1 \mathrm{H}, \mathrm{O}=\mathrm{C}-\mathrm{CH}), 3.12(\mathrm{~s}, 3 \mathrm{H}, \mathrm{CH}) .{ }^{13} \mathrm{C}-\mathrm{NMR}$ $\left(\right.$ DMSO $\left.-d_{6}\right) \delta=29.63,126.72,132.23,135.21,116.57,144.46,152.33,121.53,115.94,116.71,126.51,129.62,157.23,129.48,130.79,136.39,140.61(C=C)$, $122.37,141.63(\mathrm{CH}=\mathrm{CH}), 173.22,177.61,189.82,198.74(4 \mathrm{C}=0) \mathrm{ppm}$.

\section{Synthesis of 2-acetyl-3-((4-hydroxy-3-((E)-3-(4-nitrophenyl)-3-oxoprop-1-en-1-yl)phenyl) diazenyl) naphthalene-1,4-dione (9c)}

${ }^{1} \mathrm{H}$ NMR (400 MHz, DMSO-d $\left.d_{6}, \delta, \mathrm{ppm}\right): 7.02-8.8 .53(\mathrm{~m}, 11 \mathrm{H}, \mathrm{Ar}-\mathrm{H}),, 5.37(\mathrm{~s}, 1 \mathrm{H}, \mathrm{OH}), 6.99(\mathrm{~d}, 1 \mathrm{H}, \mathrm{CH}=), 6.86(\mathrm{~d}, 1 \mathrm{H}, \mathrm{O}=\mathrm{C}-\mathrm{CH}), 3.12(\mathrm{~s}, 3 \mathrm{H}, \mathrm{CH}) .{ }^{13} \mathrm{C}-\mathrm{NMR}$ $\left(\right.$ DMSO $\left.-d_{6}\right) \delta=29.63,126.72,132.23,135.21,116.57,144.46,152.33,121.53,115.94,116.71,126.51,129.62,157.23,124.69,130.89,144.26,153.87(C=C)$, $122.37,141.63(\mathrm{CH}=\mathrm{CH}), 173.22,177.61,189.82,198.74(4 \mathrm{C}=0) \mathrm{ppm}$.

\section{Synthesis of 2-acetyl-3-((4-hydroxy-3-((E)-3-(4-hydroxyphenyl)-3-oxoprop-1-en-1- yl)phenyl)diazenyl)naphthalene-1,4-dione (9d)}

${ }^{1} \mathrm{H}$ NMR (400 MHz, DMSO- $\left.d_{6}, \delta, \mathrm{ppm}\right): 7.02-8.8 .53(\mathrm{~m}, 11 \mathrm{H}, \mathrm{Ar}-\mathrm{H}), 5.37(\mathrm{~s}, 1 \mathrm{H}, \mathrm{OH}), 5.56(\mathrm{~s}, 1 \mathrm{H}, \mathrm{OH}), 6.99(\mathrm{~d}, 1 \mathrm{H}, \mathrm{CH}=), 6.86(\mathrm{~d}, 1 \mathrm{H}, \mathrm{O}=\mathrm{C}-\mathrm{CH}), 3.12(\mathrm{~s}, 3 \mathrm{H}, \mathrm{CH})$. ${ }^{13} \mathrm{C}-N M R\left(\right.$ DMSO- $\left.d_{6}\right) \delta=29.63,126.72,132.23,135.21,116.57,144.46,152.33,121.53,115.94,116.71,126.51,129.62,157.23,116.57,130.72,131.56$, $164.67(\mathrm{C}=\mathrm{C}), 122.37,141.63(\mathrm{CH}=\mathrm{CH}), 173.22,177.61,189.82,198.74(4 \mathrm{C}=0) \mathrm{ppm}$.

\section{Antimicrobial activity}

In present study, the synthesized compounds 4-7, 8a-c, and 9a-d were screened in-vitro against gram-positive bacteria (Streptococcus pyogenes, Staphylococcus aureus, Bacillus subtilis, Rodococcus ruber, and Enterococcus faecalis) and gram-negative bacteria ( $B$. subtilis, S. aureus, and gram-negative bacteria: E. coli, and P. aeruginosa). Further studies have been conducted to investigate the antifungal activity of the new compounds against $P$. chrysogenum, Aspergillus niger, and Candida albicans. All experiments were repeated and carried out in triplicate in the case of a significant difference in the results. The average inhibition diameters were measured in $\mathrm{mm} / \mathrm{mg}$ sample (Table 2 and Table 3 ) following Hammer et al. method [43].

In-vitro antioxidant activity

\section{DPPH antioxidant assay}

DPPH (1,1-diphenyl-2-picrylhydrazyl) free radical scavenging activity of the target compounds (4-7, 8a-c, and $\mathbf{9 a - d )}$ was calculated in terms of radical scavenging or hydrogen donating capacity using the stable radical DPPH. This assay is based on the measurement of the reducing ability of antioxidants toward DPPH. Solution of DPPH of $1 \mathrm{mM}$ in methanol was prepared and added to all the synthesized compounds (4-7, 8a-c, and 9a-d) at different concentrations $(25,50,75$, and $100 \mu \mathrm{g} / \mathrm{ml})$. The sample solutions were incubated in the dark for $30 \mathrm{~min}$ in room temperature. Subsequently, the absorbance of the samples was measured at $517 \mathrm{~nm}$ against the blank solution and the percentage (\%) of inhibition was calculated. Ascorbic acid was used as a standard antioxidant. All the spectrophotometric analyses were carried out in triplicate using a UV-Visible Spectrophotometer (Shimadzu 1700).

The percent of inhibition (I \%) of free radical production from DPPH was calculated by the following equation 
$\%$ Scavenging Activity $=\left[\left(A_{c}-A_{t}\right) / A_{c}\right] \times 100$

Where, $A=$ Absorbance of the control sample (containing all reagents except the test compound)

$A_{t}=$ Absorbance of the test sample after 30 min

The scavenging activity expressed as $\mathrm{IC}_{50}$ value (Table 4$)$, is defined as the concentration $(\mu \mathrm{g} / \mathrm{ml})$ of the synthesized compound necessary for scavenging DPPH radicals by $50 \% . \mathrm{IC}_{50}$ values were calculated by linear regression analysis using at least four different concentrations in triplicate [44].

\section{Molecular docking study}

In this work, the targets 4-9a-d were docked within glucosamine-6-phosphate synthase enzyme (GIcN-6-P) active site using molecular operating environment (MOE, version 2008.10). GlcN-6-P (PDB: IXFF) was downloaded from protein data bank (RCSB) [45]. All the targets were protonated using protonate 3D application, energy minimized by MMFF94x then docked. Docking results including docking scores and amino acids forming hydrogen bonds were determined and listed in Table 5.

Table 1

Physical data, elemental analyses, mass spectra and IR spectra of 3, 4-6, 7, 8a-c, and 9a-d.

\begin{tabular}{|c|c|c|c|c|c|c|c|c|c|c|}
\hline \multirow[t]{2}{*}{ No. } & \multirow[t]{2}{*}{ Yield\% } & \multirow[t]{2}{*}{ m.p. } & \multirow[t]{2}{*}{ Colour } & \multicolumn{4}{|c|}{$\begin{array}{l}\text { Elemental analysis : } \\
\text { Theoretical., found }\end{array}$} & \multirow{2}{*}{$\begin{array}{l}\text { Molecular formula } \\
\text { M. wt. }\end{array}$} & \multirow{2}{*}{$\begin{array}{l}\text { MS } \\
(\mathrm{El}, \\
\mathrm{m} / \mathrm{z})\end{array}$} & \multirow[t]{2}{*}{ IR: v $\left(\mathrm{cm}^{-1}\right)$} \\
\hline & & & & C & $\mathrm{H}$ & $\mathbf{N}$ & $\mathrm{Cl}$ & & & \\
\hline \multirow[t]{2}{*}{3} & \multirow[t]{2}{*}{75} & \multirow{2}{*}{$\begin{array}{l}240- \\
242\end{array}$} & \multirow[t]{2}{*}{ Red } & 65.52 & 3.47 & 8.04 & & \multirow{2}{*}{$\begin{array}{l}\mathrm{C}_{19} \mathrm{H}_{12} \mathrm{~N}_{2} \mathrm{O}_{5} \\
(348.31)\end{array}$} & \multirow[t]{2}{*}{348} & \multirow{2}{*}{$\begin{array}{l}1550(\mathrm{~N}=\mathrm{N}), 1670(\mathrm{C}=0), 1715-1615(\text { Acyclic C } \\
=0), 1650(2 \mathrm{CO} \text { Quinone ring), } 3550-3200(\mathrm{O}-\mathrm{H})\end{array}$} \\
\hline & & & & 65.56 & 3.50 & 8.07 & & & & \\
\hline \multirow[t]{2}{*}{4} & \multirow[t]{2}{*}{70} & \multirow{2}{*}{$\begin{array}{l}155 \\
- \\
152\end{array}$} & \multirow[t]{2}{*}{ green } & & 3.80 & 13.20 & & \multirow{2}{*}{$\begin{array}{l}\mathrm{C}_{24} \mathrm{H}_{16} \mathrm{~N}_{4} \mathrm{O}_{4} \\
(424.41)\end{array}$} & \multirow[t]{2}{*}{424} & \multirow{2}{*}{$\begin{array}{l}1540(\mathrm{~N}=\mathrm{N}), 1668(\mathrm{C}=\mathrm{N}), 1713-1620(\text { Acyclic C } \\
=0), 1650(2 \mathrm{CO} \text { Quinone ring), } 3550-3200(\mathrm{O}-\mathrm{H}) .\end{array}$} \\
\hline & & & & 67.96 & 3.83 & 13.25 & & & & \\
\hline \multirow[t]{2}{*}{5} & \multirow[t]{2}{*}{69} & \multirow{2}{*}{$\begin{array}{l}185- \\
187\end{array}$} & \multirow[t]{2}{*}{ yellow } & 64.94 & 3.55 & 16.46 & & \multirow{2}{*}{$\begin{array}{l}\mathrm{C}_{23} \mathrm{H}_{15} \mathrm{~N}_{5} \mathrm{O}_{4} \\
(425.40)\end{array}$} & \multirow[t]{2}{*}{425} & \multirow{2}{*}{$\begin{array}{l}1585(\mathrm{~N}=\mathrm{N}), 1662(\mathrm{C}=\mathrm{N}), 1713-1620(\text { Acyclic } C \\
=0), 1650(2 \mathrm{CO} \text { Quinone ring), } 3500-3100(\mathrm{O}-\mathrm{H}) .\end{array}$} \\
\hline & & & & 64.97 & 3.59 & 16.51 & & & & \\
\hline \multirow[t]{2}{*}{6} & \multirow[t]{2}{*}{65} & $\begin{array}{l}204- \\
206\end{array}$ & Orange & 67.53 & 4.35 & 13.13 & & $\mathrm{C}_{30} \mathrm{H}_{23} \mathrm{~N}_{5} \mathrm{O}_{5}$ & 533 & $\begin{array}{l}1554(N=N), 1560(C=N), 1713-1620 \text { (Acyclic C } \\
=0) 1650(2 C 0 \text { Ouinone }\end{array}$ \\
\hline & & & & 67.57 & 4.37 & 13.16 & & $(533.53)$ & & \\
\hline 7 & 68 & $174-$ & reddish & 66.67 & 3.41 & 6.76 & & $\mathrm{C}_{23} \mathrm{H}_{14} \mathrm{~N}_{2} \mathrm{O}_{6}$ & 414 & $1550(\mathrm{~N}=\mathrm{N}), 1705(\mathrm{C}=0), 1713-1620($ Acyclic $\mathrm{C}=$ \\
\hline & & & & 66.71 & 3.46 & 6.79 & & $(414.37)$ & & chromen). \\
\hline $8 a$ & 64 & $218-$ & yellow & 71.71 & 3.61 & 5.58 & & $\mathrm{C}_{30} \mathrm{H}_{18} \mathrm{~N}_{2} \mathrm{O}_{6}$ & 502 & $1559(N=N), 1637(C=C$ of chalcon $), 1675(C=0)$, \\
\hline & & & & 66.75 & 3.51 & 6.82 & & $(502.47)$ & & ring), $1740(\mathrm{C}=\mathrm{O}$ of chromen). \\
\hline $8 b$ & 60 & $239-$ & pall & 67.11 & 3.19 & 5.22 & 6.60 & $\mathrm{C}_{30} \mathrm{H}_{17} \mathrm{ClN}_{2} \mathrm{O}_{6}(536.92)$ & 536 & $1590(\mathrm{~N}=\mathrm{N}), 1639(\mathrm{C}=\mathrm{C}$ of chalcon $), 1678(\mathrm{C}=0)$, \\
\hline & & & & 67.15 & 3.23 & 5.25 & 6.65 & & & ring), 1740 ( $\mathrm{C}=\mathrm{O}$ of chromen). \\
\hline $8 c$ & 63 & $256-$ & deep & 69.50 & 3.50 & 5.40 & & $\mathrm{C}_{30} \mathrm{H}_{18} \mathrm{~N}_{2} \mathrm{O}_{7}$ & 518 & $1554(\mathrm{~N}=\mathrm{N}), 1634(\mathrm{C}=\mathrm{C}$ of chalcon $), 1675(\mathrm{C}=0)$, \\
\hline & & & & 69.53 & 3.56 & 5.44 & & $(518.47)$ & & ring), $1740(\mathrm{C}=\mathrm{O}$ of chromen). \\
\hline 9a & 70 & $\begin{array}{l}160- \\
162\end{array}$ & Orange & 69.67 & 4.11 & 9.03 & & $\mathrm{C}_{27} \mathrm{H}_{19} \mathrm{~N}_{3} \mathrm{O}_{5}$ & 465 & $\begin{array}{l}1556(\mathrm{~N}=\mathrm{N}), 1630(\mathrm{C}=\mathrm{C} \text { of chalcon }), 1713-1620 \\
\text { (Acyclic } \mathrm{C}=0)) 1650 \text { (2 CO Ouinone ring) } 1651\end{array}$ \\
\hline & & & & 69.70 & 4.15 & 9.06 & & $(465.46)$ & & $(\mathrm{C}=0), 3223(\mathrm{OH}), 3440\left(\mathrm{NH}_{2}\right)$ \\
\hline $9 b$ & 74 & $182-$ & brown & 66.88 & 3.53 & 5.78 & 7.31 & $\mathrm{C}_{27} \mathrm{H}_{17} \mathrm{ClN}_{2} \mathrm{O}_{5}(484.89)$ & 484 & $1588(\mathrm{~N}=\mathrm{N}), 1639(\mathrm{C}=\mathrm{C}$ of chalcon $), 1713-1620$ \\
\hline & & & & 66.92 & 3.56 & 5.83 & 7.35 & & & $=0), 3226(\mathrm{OH})$ \\
\hline 9c & 72 & $151-$ & deep & 65.45 & 3.46 & 8.48 & & $\mathrm{C}_{27} \mathrm{H}_{17} \mathrm{~N}_{3} \mathrm{O}_{7}$ & 495 & $1520,1344\left(\mathrm{NO}_{2}\right), 1585(\mathrm{~N}=\mathrm{N}), 1628(\mathrm{C}=\mathrm{C}$ of \\
\hline & & & & 65.48 & 3.49 & 8.51 & & $(495.44)$ & & $\begin{array}{l}\text { chalcon), 1713-1620 (Acyclic C = 0), } 1650(2 \mathrm{CO} \\
\text { Quinone ring), } 1666(\mathrm{C}=0), 3200-3400(\mathrm{OH}) .\end{array}$ \\
\hline $9 d$ & 69 & $\begin{array}{l}137- \\
139\end{array}$ & violet & 69.52 & 3.89 & 6.01 & & $\mathrm{C}_{27} \mathrm{H}_{18} \mathrm{~N}_{2} \mathrm{O}_{6}$ & 466 & $1535(\mathrm{~N}=\mathrm{N}), 1623(\mathrm{C}=\mathrm{C}$ of chalcon $), 1713-1620$ \\
\hline & & & & 69.56 & 3.93 & 6.05 & & $(466.44)$ & & $=0), 3200-3400(\mathrm{OH})$ \\
\hline
\end{tabular}

\section{Results And Discussion}

\section{Chemistry}

The required starting azo compound, 5-((3-acetyl-1,4-dioxo-1,4-dihydronaphthalen-2-yl)diazenyl)-2-hydroxybenzaldehyde (3) was synthesized with good yield by diazotization of 2-acetyl-3-aminonaphthalene-1, 4-dione (1) and coupling with salicylaldehyde according to a previous reported method [46] (Scheme 1). 
The structure identification of all the synthesized compounds was deduced from the spectroscopic data (Mass spectrometry, ${ }^{13} \mathrm{C}-\mathrm{NMR},{ }^{1} \mathrm{H}-\mathrm{NMR}$, and FTIR). The FTIR spectra of compound 3 revealed the presence of a stretching band at about $1550 \mathrm{~cm} \otimes^{1}$ corresponding to the $\mathrm{N}=\mathrm{N}$ group and a stretching abroad band around $3550-3200(\mathrm{O}-\mathrm{H}) \mathrm{cm}^{-1}$ due to the intramolecular hydrogen bonding of the hydroxyl group. On the other hand, the ${ }^{1} \mathrm{H}-\mathrm{NMR}$ spectrum of compound 3 displayed singlets at 5.43 ppm and 7.02-8.02 ppm assignable to the O-H proton and the proton of salicylaldehyde and aromatic ring, respectively. Moreover, the ${ }^{1} \mathrm{H}-\mathrm{NMR}$ spectrum of compound $\mathbf{3}$ exhibited a singlet at $10.41 \mathrm{ppm}$ corresponding to the proton of the aldehyde group.

The condensation of 5-((3-acetyl-1,4-dioxo-1,4-dihydronaphthalen-2-yl)diazenyl)-2-hydroxybenzaldehyde (3) with aromatic amine in absolute ethanol yielded the Schiff bases (4-6). The FT-IR spectra of these compounds showed the presence of the azomethine $\mathrm{CH}=\mathrm{N}$ stretching at about $1668-1666 \mathrm{~cm}^{-1}$. Besides, the ${ }^{1} \mathrm{H}-\mathrm{NMR}$ spectrum of compound $\mathbf{4}$ exhibited singlet signals at 5.42 and $2.54 \mathrm{ppm}$ corresponding to the proton of hydroxyl and methyl groups, respectively. A multiplet signals at 7.02-8.8.53 ppm were ascribed to the aromatic proton and the proton of $\mathrm{CH}=\mathrm{N}$ group. The Knoevenagel condensation [47] of 5-( 3 acetyl-1,4-dioxo-1,4-dihydronaphthalen-2-yl)diazenyl)-2-hydroxybenzaldehyde (3) with ethyl acetoacetate in the presence of piperidine as catalyst yielded 2acetyl-3-((3-acetyl-2-oxo-2H-chromen-6-yl)diazenyl)naphthalene-1,4-dione (7). The chemical structure of compound 7 was confirmed by the FTIR spectra through the simultaneous disappearance of the $0-\mathrm{H}$ stretching frequency and the $\mathrm{C}=0$ band of aldehyde, and the appearance of bands at $1740 \mathrm{~cm}^{-1}$ and $1705 \mathrm{~cm}^{-1}$ corresponding to the $\mathrm{C}=\mathrm{O}$ of chromene ring and the $\mathrm{C}=\mathrm{O}$ of acetyl group, respectively. Additionally, the ${ }^{1} \mathrm{H}-\mathrm{NMR}$ spectrum of compound 7 exhibited singlet signals at $2.25 \mathrm{ppm}$ due to the protons of acetyl group pm and $3.11 \mathrm{pm}$ corresponding to the $\mathrm{CH}_{3}$ group. The multiplet signals at $7.02-8.8 .53$ ppm were assigned to the $17 \mathrm{H}$ aromatic protons.

Due to the medicinal features of chalcone derivatives, many efforts have been made in this study to further design potent bioactive chalcones derivatives bearing 1,4-naphthoquinone moiety. For this purpose, compound 7 was reacted with p-substituted benzaldehyde to afford three-chalcone derivatives 8 a-c (Scheme 2). All these reactions proceeded smoothly and provided the corresponding compounds $8 \mathrm{a}-\mathrm{c}$ with good yields varying between 60 and $64 \%$. These new compounds were characterized and identified by spectral data. The FT-IR spectra of compound 8 a exhibited absorption bands at $1637,1675 \mathrm{~cm} \mathbf{1}^{1}$ corresponding to the $\mathrm{C}=\mathrm{C}$ and the $\mathrm{C}=\mathrm{O}$ of $\mathrm{a}, \beta$-unsaturated compound respectively. In the ${ }^{1} \mathrm{H}$ - and $13 \mathrm{C}$-NMR, all the expected signals were observed in their expected shifts and multiplicities (See experimental section). For instance, the ${ }^{1} \mathrm{H}-\mathrm{NMR}$ spectrum of compound $8 \mathrm{a}$ exhibited doublet signal at $6.75 \mathrm{ppm}$ for one proton $\mathrm{O}=\mathrm{C}-\mathrm{CH}$, doublet signal at $6.96 \mathrm{ppm}$ for one proton $\mathrm{CH}=$, and multiplet signals at $7.02-8.8 .53 \mathrm{ppm}$ due to the $13 \mathrm{H}$ aromatic protons.

The condensation of compound $\mathbf{3}$ with various para-substituted acetophenone afforded the corresponding chalcones 9a-d (Scheme 3 ). FTIR spectra of chalcone 9 a showed bands at $1630 \mathrm{~cm}^{-1}$ and $1651 \mathrm{~cm}^{-1}$ attributed to $\mathrm{C}=\mathrm{C}$ and $\mathrm{C}=0$ of $\mathrm{a}, \beta$ - unsaturated respectively. The chemical structures of compounds 9a-d were established by their elemental and spectral analysis. All compounds displayed a molecular ion corresponding to the molecular mass, and both fragments were consistent with the chalcones structures.

\section{Biological activity and SAR studies}

\subsubsection{In-vitro antibacterial and antifungal activity}

After the successful synthesis and elucidation of the chemical structures of compounds 4, 5, 6, 7, 8a-c, and 9a-d, we assessed their in-vitro antibacterial activity against Gram-positive bacteria (Streptococcus Pyogenes, Staphylococcus Aureus, Bacillus subtilis, Rodococcus ruber, Enterococcus faecalis), Gramnegative bacteria (Pseudomonas aeruginosa, Escherichia coli, Salmonella typhimurium, Acinetobacter calcoaceticus). They were also evaluated for their antifungal activities against $P$. chrysogenum, A. niger, Aspergillus niger, Candida albicans).

Ciprofloxacin and fluconazole were used as a reference drugs and the mean inhibition diameter values $(n=3)$ were presented in Table 2 and Table 3 in $\mathrm{mm} / \mathrm{mg}$ sample.

Mainly, all the tested compounds exhibited a comparatively promising activity against gram-positive and gram-negative bacteria.

From Table 2 and Table 3, we can deduce that compounds $\mathbf{9 b}$ and $\mathbf{9 c}$ revealed the highest efficacy against both bacterial and fungal species with inhibition zone diameters exceeding that of the reference ciprofloxacin and fluconazole, respectively. Compound $\mathbf{9 c}$ exhibited the highest antibacterial activity against Rodococcus ruber, Bacillus subtilis bacteria, Enterococcus faecalis, Streptococcus Pyogenes with an inhibition zone diameter ( $\mathrm{d}=28 \mathrm{~mm} / \mathrm{mg}$ sample) exceeding that of the reference ( $d=25 \mathrm{~mm} / \mathrm{mg}$ sample). Furthermore, compounds $\mathbf{6}, \mathbf{8 a}, \mathbf{8 b}, \mathbf{8 c}, \mathbf{9 a}$ and $\mathbf{9 d}$ presented good antibacterial activity towards the tested bacterial and fungal strains.

Structure-activity relationship (SAR) studies were realized to better figure out the effect of substituents present at the para position of the phenyl moiety in compounds $\mathbf{8 a - c}$ and $\mathbf{9 a - d}$ on the gram-positive, gram-negative bacteria and fungal strains (Table 2 and Table 3 ). It was suggested that the presence of electron-withdrawing chloro (8b, 9b) nitro group (9c) at the para position of the phenyl ring enhances meaningfully their antibacterial and antifungal activity. On the other hand, the presence of electrodonating amino $(9 \mathrm{a}, 9 \mathrm{~d})$ and hydroxyl group at the 4-position of the phenyl moiety decreased slightly their antibacterial and antifungal activity towards all the tested strains.

It is worth noting that compounds $\mathbf{4 , 5 , 6}$, and $\mathbf{7}$ displayed the least antibacterial and antifungal activity against the tested strains since they showed almost similar inhibition zone diameters.

Further SAR studies were conducted to understand better the effect of the aromatic substituents attached to the diazenyl group of compounds 4-6 on the bacterial and fungal species. It was found that the presence of pyridine 4, pyrimidine 5, 4-amino antipyrine (6) has moderate effect on their antibacterial and antifungal activity. In fact, the presence of the antipyrine moiety enhanced slightly the antibacterial activity of compound $\mathbf{6}$ compared to compounds $\mathbf{4}$ and $\mathbf{5}$ against Staphylococcus Aureus, Bacillus subtilis, Rodococcus ruber, Enterococcus faecalis, all the tested gram-negative bacteria, and P. Chrysogenum. In the 
other hand, the of pyridine ring attached to the diazenyl group ameliorated slightly the antibacterial and antifungal activity of compound 4 against Streptococcus Pyogenes and Aspergillus niger and Candida albicans compared to compounds $\mathbf{5}$ and $\mathbf{6}$.

Table 2

Antibacterial evaluation of the newly synthesized compounds against gram-positive and gram-negative bacteria.

\begin{tabular}{|c|c|c|c|c|c|c|c|c|c|}
\hline \multirow{3}{*}{$\begin{array}{l}\text { Compound } \\
\text { no. }\end{array}$} & \multicolumn{9}{|c|}{ Bacterial species } \\
\hline & \multicolumn{5}{|c|}{ Gram-positive bacteria } & \multicolumn{4}{|c|}{ Gram-negative bacteria } \\
\hline & $\begin{array}{l}\text { Streptococcus } \\
\text { pyogenes }\end{array}$ & $\begin{array}{l}\text { Staphylococcus } \\
\text { aureus }\end{array}$ & $\begin{array}{l}\text { Bacillus } \\
\text { subtilis }\end{array}$ & $\begin{array}{l}\text { Rodococcus } \\
\text { ruber }\end{array}$ & $\begin{array}{l}\text { Enterococcus } \\
\text { faecalis }\end{array}$ & $\begin{array}{l}\text { Pseudomonas } \\
\text { aeruginosa }\end{array}$ & $\begin{array}{l}\text { Escherichia } \\
\text { coli }\end{array}$ & $\begin{array}{l}\text { Salmonella } \\
\text { typhimurium }\end{array}$ & $\begin{array}{l}\text { Acinetobs } \\
\text { calcoacet }\end{array}$ \\
\hline & \multicolumn{9}{|c|}{ Inhibition zone diameter ( $\mathrm{mm} / \mathrm{mg}$ sample) ${ }^{a}$} \\
\hline 4 & 15 & 13 & 14 & 15 & 12 & 13 & 11 & 15 & 17 \\
\hline 5 & 14 & 15 & 12 & 18 & 14 & 15 & 16 & 13 & 21 \\
\hline 6 & 13 & 17 & 18 & 18 & 15 & 16 & 18 & 15 & 22 \\
\hline 7 & 14 & 17 & 16 & 21 & 19 & 14 & 15 & 17 & 23 \\
\hline $8 a$ & 14 & 24 & 18 & 23 & 17 & 15 & 23 & 19 & 22 \\
\hline $8 b$ & 19 & 21 & 22 & 22 & 18 & 17 & 22 & 20 & 23 \\
\hline $8 c$ & 14 & 18 & 18 & 23 & 15 & 16 & 19 & 19 & 21 \\
\hline $9 a$ & 15 & 22 & 15 & 21 & 19 & 17 & 21 & 16 & 22 \\
\hline $9 b$ & 22 & 29 & 21 & 23 & 22 & 20 & 27 & 20 & 24 \\
\hline $9 c$ & 23 & 28 & 23 & 28 & 25 & 24 & 28 & 21 & 29 \\
\hline $9 d$ & 20 & 21 & 21 & 23 & 20 & 19 & 23 & 19 & 22 \\
\hline Ciprofloxacin & 22 & 25 & 18 & 25 & 22 & 22 & 25 & 18 & 25 \\
\hline DMSO & 0 & 0 & 0 & 0 & 0 & 0 & 0 & 0 & 0 \\
\hline
\end{tabular}

a The mean values of three experiments are given.

Table 3

\begin{tabular}{|c|c|c|c|}
\hline Compounds & P. chrysogenum & $\begin{array}{l}\text { Aspergillus } \\
\text { niger }\end{array}$ & $\begin{array}{l}\text { Candida } \\
\text { albicans }\end{array}$ \\
\hline 4 & 10 & 16 & 15 \\
\hline 5 & 11 & 16 & 12 \\
\hline 6 & 14 & 11 & 10 \\
\hline 7 & 10 & 15 & 18 \\
\hline $8 a$ & 12 & 13 & 10 \\
\hline $8 b$ & 13 & 16 & 15 \\
\hline $8 c$ & 10 & 14 & 16 \\
\hline $9 a$ & 11 & 15 & 10 \\
\hline $9 b$ & 19 & 14 & 21 \\
\hline $9 c$ & 21 & 17 & 19 \\
\hline 9d & 12 & 10 & 13 \\
\hline Flucanazole & 18 & 19 & 20 \\
\hline DMSO & 0 & 0 & 0 \\
\hline
\end{tabular}

\section{Antioxidant activity}

Naphthoquinones possess redox and electrophile properties and can play the role of pro- or anti-oxidants through their direct molecular action or by their interactions with various enzymes, which can adjust the oxidative conditions of the cells [48]. Previous studies suggested that phenolic compounds have the capacity to act as hydrogen donors [49] and the presence of the phenol moiety in the structure of the target molecules was related but not constantly proportional to the scavenging capacity [50]. Free radical scavenging is among the best-known mechanisms for testing preliminary free radical-scavenging activity in which antioxidants inhibit lipid oxidation [51]. 
In this study, the in-vitro antioxidant activity of the synthesized compounds 4-7, 8a-c, and 9a-d was assessed using a UV-Visible spectrophotometry by DPPH radicals, and the obtained results are depicted in Table 4. In fact, DPPH are stable free radicals and their radical character is neutralized in the presence of molecules able of donating hydrogen atoms. In other words, DPPH method is commonly used to measure the ability of antioxidants to sweep free radicals. Previous studies [52] using DPPH method have highlighted that compounds exhibiting potent antioxidant properties must have strong hydrogen donor groups.

Consistent with this finding, we noted from Table 4 and Fig. 1 that the synthesized derivatives $9 d, 9 a, 9 b, 8 c$, and 6 displayed the highest radical scavenging activity compared to the other compounds. Their behavior was ascribed to the presence of electron donating groups attached to the phenyl ring, such as amino (9a), chloro (9b), and hydroxyl (9d, 8c) groups, compared to the standard ascorbic acid. Besides, the good antioxidant activity of compound 6 might be related to the presence of the carbonyl group in the 4- aminoantipyrine attached to the diazenyl group, which is a potential donor due to the large dipole moment (5.48 D) and display strong basic characters [53]. Compound $9 \mathbf{c}$ showed moderate antioxidant activity compared to the previous compounds, this result was assigned to the presence of the withdrawing nitro group at the para position of the benzene ring. In contrast, compound $\mathbf{7}$ had the lowest antioxidant activity compared to ascorbic acid among all the tested compound, this finding was attributed to the presence of withdrawing acetyl group attached at the 2-position of the chromene ring $\left(\mathrm{IC}_{50}=23.30 \pm 1.09\right)$. Similarly, we found that of pyridine ring, pyrimidine, and 4 -aminoantipyrine attached to the diazenyl group of the Schiff bases $\mathbf{4}, \mathbf{5}$ and $\mathbf{6}$, respectively caused the inhibition to decrease compared to the ascorbic acid.

The obtained data from the DPPH radical scavenging method showed that compounds $9 \mathrm{~d}$ and $9 \mathrm{a}$ exhibited the strongest inhibition mainly at $\mathrm{C}=100 \mu \mathrm{g} / \mathrm{mL}$ as presented in Table 4 and their radical scavenging activities were very close from that of ascorbic acid (87.19 \pm 0.54$)$.

Table 4

The in vitro antioxidant activity of the synthesized compound in DPPH method.

\begin{tabular}{|c|c|c|c|c|c|}
\hline \multirow[t]{2}{*}{ Compound no. } & \multicolumn{5}{|c|}{ Concentration ( $\mu \mathrm{g} / \mathrm{ml})$} \\
\hline & 25 & 50 & 75 & 100 & $\mathrm{IC}_{50}$ \\
\hline 4 & $52.86 \pm 1.24$ & $58.29 \pm 1.12$ & $61.94 \pm 1.32$ & $64.20 \pm 1.05$ & $22.98 \pm 0.69$ \\
\hline 5 & $63.87 \pm 0.71$ & $67.81 \pm 1.60$ & $72.16 \pm 0.95$ & $77.42 \pm 0.45$ & $19.31 \pm 1.13$ \\
\hline 6 & $66.28 \pm 1.12$ & $69.80 \pm 1.55$ & $71.86 \pm 1.57$ & $74.51 \pm 0.61$ & $18.25 \pm 1.10$ \\
\hline 7 & $47.38 \pm 1.17$ & $53.08 \pm 0.89$ & $56.49 \pm 1.24$ & $60.98 \pm 1.52$ & $23.30 \pm 1.09$ \\
\hline $8 a$ & $58.12 \pm 0.97$ & $63.84 \pm 1.58$ & $67.84 \pm 1.57$ & $71.59 \pm 1.37$ & $20.18 \pm 0.78$ \\
\hline $8 b$ & $64.61 \pm 1.05$ & $69.22 \pm 1.57$ & $73.89 \pm 1.07$ & $74.21 \pm 0.43$ & $19.41 \pm 1.23$ \\
\hline $8 c$ & $68.39 \pm 0.90$ & $70.59 \pm 0.26$ & $74.06 \pm 0.94$ & $79.53 \pm 0.37$ & $18.25 \pm 1.10$ \\
\hline $9 a$ & $77.43 \pm 0.27$ & $80.68 \pm 0.45$ & $84.39 \pm 0.46$ & $85.78 \pm 0.79$ & $17.37 \pm 0.31$ \\
\hline $9 b$ & $73.48 \pm 0.39$ & $76.54 \pm 0.63$ & $79.34 \pm 0.52$ & $84.15 \pm 0.64$ & $18.35 \pm 0.49$ \\
\hline $9 c$ & $71.53 \pm 0.25$ & $75.18 \pm 0.46$ & $78.74 \pm 0.46$ & $82.84 \pm 0.39$ & $18.40 \pm 0.41$ \\
\hline 9d & $73.89 \pm 0.19$ & $77.42 \pm 0.45$ & $80.61 \pm 0.48$ & $85.83 \pm 0.54$ & $16.89 \pm 0.58$ \\
\hline Ascorbic acid & $83.66 \pm 0.13$ & $84.58 \pm 0.37$ & $85.56 \pm 0.45$ & $87.19 \pm 0.54$ & $15.16 \pm 0.43$ \\
\hline Blank & - & - & - & - & - \\
\hline
\end{tabular}

(-) Showed no scavenging activity. Values were the means of three replicates \pm SD.

\section{Molecular docking study}

In the present work, docking studies were carried out to obtain accurate predictions on the optimized conformations for both the new synthesized derivatives and protein targets to form a stable complex and to have a better insight into the structure-activity relationships (SARs) of the novel compounds. Glucosamine-6-phosphate synthase enzyme (GlcN-6-P) has been proposed as a promising target for many antimicrobial agents since this enzyme is important for ammonia transferring from L-glutamine to fructose-6-phosphate and then transform by isomerization the produced fructosamine to glucosamine-6-phosphate, which is essential for cell wall formation [54-56]. To explore the binding modes of the novel candidates, all these candidates 4-9ad were docked inside the active site of GlcN-6-P using a molecular operating environment (MOE, version 2008.10). 3D crystal structure of this enzyme was obtained from a protein data bank (PDB: 1XFF). The data obtained from docking the newly synthesized derivatives, inside GlcN-6-P, including hydrogen bonding, energy scores, and the essential functional groups, are listed in Table 5. The co-crystallized ligand glutamate was redocked within GlcN-6-P with RMSD $=1.2557$, In addition, glutamate displayed hydrogen bondings with Gly99, Trp74, Cys1, His86, Arg73, Thr76 and, Asp123 with binding score energy = $-15.11 \mathrm{kcal} / \mathrm{mol}$. The compound $9 \mathrm{c}$ recorded four hydrogen-bonding interactions within the active site as follows: a) Trp74 with carbonyl group, b) Cys 1 with the carbonyl group, c) Pro177 with hydroxyl group via a water molecule, and d) Ser176 with hydroxyl group via a water molecule (Fig. 1).

Furthermore, compound $9 \mathrm{~b}$ showed a high binding score $(-16.01 \mathrm{Kcal} / \mathrm{mol})$ and was detected to form four hydrogen bonds with His71, Cys1, and Trp74 throughbinding with $\mathrm{C}=\mathrm{O}$ and $\mathrm{OH}$ moieties (Fig. 2). 
Regarding compound $\mathbf{8 b}$, the two carbonyl groups formed three hydrogen bonds with Gly99, Cys 1 , and Thr76 with a binding docking score equals to -15.43 $\mathrm{Kcal} / \mathrm{mol}$. In addition to revealing arene-arene interaction with Trp74 (Fig. 3).

Furthermore, compound $9 \mathrm{~d}$ displayed a binding energy equals to $-15.05 \mathrm{Kcal} / \mathrm{mol}$ with four hydrogen bonds as follows: a) Arg73 with $\mathrm{OH}$, b) His86 with $\mathrm{OH}, \mathrm{c}$ ) Trp74 with $\mathrm{OH}$ and d) Cys 1 with $\mathrm{C}=0$. in addition to arene-arene interaction between Trp74 and phenyl moiety (Fig. 4).

Moreover, the target 7 demonstrated arene-arene binding between His97 and phenyl moiety, in addition to six hydrogen bonding with His86, Arg73, His77, Thr76, and Ser176 with a binding energy score of $-12.87 \mathrm{Kcal} / \mathrm{mol}$ (Fig. 5). 
Table 5

Docking study results for compounds 4-9a-d and the cocrystallized ligand glutamate inside GlcN-6-P active site.

\begin{tabular}{|c|c|c|c|c|c|}
\hline Compounds & $\begin{array}{l}\text { Affinity } \\
\mathrm{Kcal} / \mathrm{mol}\end{array}$ & No. of hydrogen bonds & \multicolumn{2}{|c|}{$\begin{array}{l}\text { Distance }(\AA) \text { from main } \\
\text { residue }\end{array}$} & \multirow{2}{*}{$\begin{array}{l}\text { Functional } \\
\text { group } \\
\mathrm{OH}\end{array}$} \\
\hline 4 & -13.56 & 3 & Cys1 & 2.67 & \\
\hline & & & Trp74 & 3.11 & $\mathrm{OH}$ \\
\hline & & & His86 & 2.88 & Pyridine N \\
\hline \multirow[t]{4}{*}{5} & -13.22 & 4 & His77 & 3.24 & Pyridine N \\
\hline & & & Thr76 & 3.26 & Pyridine $\mathrm{N}$ \\
\hline & & & Trp74 & 3.27 & $\mathrm{OH}$ \\
\hline & & & Ser176 & 2.48 & $C=0$ \\
\hline \multirow[t]{4}{*}{6} & -13.05 & 4 & Thr76 & 2.27 & $C=0$ \\
\hline & & & Cys1 & 2.90 & $C=0$ \\
\hline & & & Cys1 & 3.21 & $C=0$ \\
\hline & & & Trp74 & 3.39 & $C=0$ \\
\hline \multirow[t]{6}{*}{7} & -12.87 & 6 & His86 & 2.82 & $C=0$ \\
\hline & & & Arg73 & 2.76 & $C=0$ \\
\hline & & & Arg73 & 3.13 & $C=0$ \\
\hline & & & His77 & 3.86 & $C=0$ \\
\hline & & & Thr76 & 3.56 & $C=0$ \\
\hline & & & Ser176 & 2.98 & $C=0$ \\
\hline \multirow[t]{3}{*}{$8 a$} & -12.66 & 3 & Gly99 & 2.62 & $C=0$ \\
\hline & & & Cys1 & 2.49 & $C=0$ \\
\hline & & & Thr76 & 3.45 & $C=0$ \\
\hline \multirow[t]{3}{*}{$8 b$} & -15.43 & 3 & Gly99 & 2.72 & $C=0$ \\
\hline & & & Cys1 & 2.99 & $C=0$ \\
\hline & & & Thr76 & 3.01 & $C=0$ \\
\hline \multirow[t]{5}{*}{$8 c$} & -15.68 & 5 & Thr76 & 2.92 & $C=0$ \\
\hline & & & His77 & 3.12 & $C=0$ \\
\hline & & & Arg73 & 2.82 & $C=0$ \\
\hline & & & Arg73 & 2.77 & $C=0$ \\
\hline & & & Cys1 & 2.05 & $\mathrm{OH}$ \\
\hline \multirow[t]{4}{*}{$9 a$} & -15.21 & 4 & Asp123 & 2.77 & $\mathrm{NH}_{2}$ \\
\hline & & & Thr124 & 2.91 & $\mathrm{NH}_{2}$ \\
\hline & & & Trp74 & 3.09 & $C=0$ \\
\hline & & & Cys1 & 3.87 & $C=0$ \\
\hline \multirow[t]{4}{*}{$9 b$} & -16.01 & 4 & His71 & 2.44 & $C=0$ \\
\hline & & & Cys1 & 3.01 & $C=0$ \\
\hline & & & Cys1 & 2.66 & $\mathrm{OH}$ \\
\hline & & & Trp74 & 2.78 & $\mathrm{OH}$ \\
\hline \multirow[t]{4}{*}{$9 c$} & -14.87 & 4 & Trp74 & 2.11 & $C=0$ \\
\hline & & & Cys1 & 2.23 & $C=0$ \\
\hline & & & Pro177 & 2.89 & $\mathrm{OH}$ \\
\hline & & & Ser176 & 3.28 & $C=0$ \\
\hline
\end{tabular}




\begin{tabular}{|c|c|c|c|c|c|}
\hline \multirow{2}{*}{$\begin{array}{l}\text { Compounds } \\
\text { 9d }\end{array}$} & \multirow{2}{*}{$\begin{array}{l}\text { Affinity } \\
\text { Kcal/mol } \\
-15.05\end{array}$} & \multirow{2}{*}{$\begin{array}{l}\text { No. of hydrogen bonds } \\
4\end{array}$} & \multicolumn{2}{|c|}{$\begin{array}{l}\text { Distance }(\AA) \text { from main } \\
\text { residue }\end{array}$} & \multirow{2}{*}{$\begin{array}{l}\text { Functional } \\
\text { group } \\
\mathrm{OH}\end{array}$} \\
\hline & & & His86 & 2.41 & \\
\hline & & & Arg73 & 2.56 & $\mathrm{OH}$ \\
\hline & & & Cys1 & 2.77 & $C=0$ \\
\hline & & & Trp74 & 3.11 & $\mathrm{OH}$ \\
\hline \multirow[t]{10}{*}{ Glutamate } & -15.11 & 10 & Gly99 & 2.02 & $C=0$ \\
\hline & & & Trp74 & 2.06 & $\mathrm{CO}-$ \\
\hline & & & Cys1 & 2.54 & $\mathrm{CO}-$ \\
\hline & & & His86 & 1.77 & $\mathrm{CO}-$ \\
\hline & & & Arg73 & 2.70 & $\mathrm{CO}-$ \\
\hline & & & Arg73 & 3.05 & $C=0$ \\
\hline & & & Thr76 & 2.70 & $C=0$ \\
\hline & & & Asp123 & 3.05 & $\mathrm{NH}$ \\
\hline & & & Thr76 & 2.70 & $\mathrm{NH}$ \\
\hline & & & Gly99 & 3.07 & $\mathrm{NH}$ \\
\hline
\end{tabular}

\section{Conclusion}

A convenient, efficient, and economical protocol has been described herein for the synthesis of new derivatives bearing 1,4-naphthoquinone moiety. All the designed compounds $\mathbf{4}-\mathbf{7}, \mathbf{8 a}-\mathbf{c}$, and $\mathbf{9 a - d}$ were assessed for their in-vitro antimicrobial activity against gram-positive, gram-negative bacteria, and fungal strains. Further studies have been conducted to evaluate the antioxidant activity of the synthesized compounds using the DPPH method. Based on the overall results, it was found that compounds $\mathbf{8 b}, \mathbf{9 b}$, and $\mathbf{9 c}$ displayed the highest efficacy against both bacterial and fungal strains compared to the other compounds. The structure-activity relationship (SAR) studies suggested that the presence of electron-withdrawing groups (chloro and nitro) at the para position of the phenyl ring increases the antibacterial and antifungal activity of the compounds compared to those possessing electrodonating groups (amino and hydroxyl) at the same position. The antioxidant studies revealed that compounds $9 \mathrm{~d}, 9 \mathrm{a}, 9 \mathrm{~b}, \mathbf{8 c}$, and 6 displayed the highest radical scavenging activity. This finding was attributed to the presence of electron-donating substituents related to the phenyl ring, such as amino $9 \mathrm{a}$, chloro $9 \mathrm{~b}$, and hydroxyl (9d, $8 \mathrm{c}$ ) groups of these compounds. The conducted molecular docking studies ascertained that the most active antimicrobial compounds displayed good energy binding scores within the GLN-6-P active site, suggesting that they can act by the inhibition of DNA replication.

\section{Declarations}

\section{Acknowledgements}

The authors gratefully acknowledge financial support from Jouf University (Kingdom of Saudi Arabia), and Aswan University (Egypt).

\section{Conflict of interest}

The authors declare that there are no conflicts of interest regarding the publication of this paper.

\section{References}

1. Jampilek J (2019) Heterocycles in Medicinal Chemistry. Molecules $24: 3839$

2. Gomtsyan A (2012) Heterocycles in drugs and drug discovery. Chem Heterocycl Compd 48: 7-10.

3. Broughton HB, Watson IA (2004) Selection of Heterocycles for drug design. J Mol Graph Model 23: 51-58.

4. ElKanzi NAA, Ghoneim AA, Hrichi H (2019) Synthesis and antimicrobial evaluation of novel pyrazole, imidazole and pyrimidine derivatives possessing imidazo[4,5-B]indol moiety.Cjm 14: 105-116

5. Zhou B, Xing C (2015) Diverse Molecular Targets for Chalcones with Varied Bioactivities. Med Chem 5: 388-404

6. Sahu NK, Balbhadra SS, Choudhary J, Kohli DV (2012) Exploring pharmacological significance of chalcone scaffold: a review. Curr Med Chem 19: 209225

7. Singh P, Anand A, Kumar V (2014) Recent developments in biological activities of chalcones: a mini review. Eur J Med Chem 85: 758-777

8. Yang HM, Shin HR, Cho SH, Bang SC, Song GY, Ju JH (2007) Structural requirement of chalcones for the inhibitory activity of interleukin-5. Bioorg Med Chem 15: 104-111

9. Panchal AD, Prashant D, Patel KM (2011) Synthesis and Biological Evaluation of Chalcone Derivatives. IJPSDR 3:331-337 
10. Alcaraz LE, Blanco SE, Puig ON, Tomas F, Ferretti FH (2000) Antibacterial activity of flavonoids against methicillin-resistant Staphylococcus aureus strains. J Theor Biol 205:231-240.

11. Man X, Piye W, Shen F, Jiayou J, Rakesh KP (2019) Chalcone derivatives and their antibacterial activities: Current development. Bioorg Chem 91:103-113

12. Liu M, Wilairat P, Go ML (2001) Antimalarial Alkoxylated and Hydroxylated Chalones: Structure-Activity Relationship Analysis. J Med Chem 44:44 434452

13. Lee YH, Jeon SH, Kim SH, Kim C, Lee SJ, Koh D, Lim Y, Ha K, Shin SY (2012) A new synthetic chalcone derivative, 2hydroxy-3',5,5'-trimethoxychalcone (DK139), suppresses the Tolllike receptor 4-mediated inflammatory response through inhibition of the Akt/NF-kappaB pathway in BV2 microglial cells. Exp Mol Med 44:369-377

14. Haraguchi H, Inoue J, Tamura Y, Mizutani K (2002) Antioxidative components of Psoralea corylifolia (Leguminosae). Phytother Res 16: $539-544$

15. Pesaran Seiied Bonakdar A, Vafaei F, Farokhpour M, Nasr Esfahani M, Massah AR (2017) Synthesis and Anticancer Activity Assay of Novel ChalconeSulfonamide Derivatives. IJPR 16: 565-568

16. Caamal-Fuentes EE, Peraza-Sanchez SR, Torres-Tapia LW, Moo-Puc RE (2015) Isolation and Identification of Cytotoxic Compounds from Aeschynomene fascicularis, a Mayan Medicinal Plant. Molecules 20:13563-13574

17. Go ML, Wu X, Liu XL (2005) Chalcones: an update on cytotoxic and chemoprotective properties. Curr Med Chem 12:481-499

18. Ibis C, Tuyun AF, Ozsoy-Gunes Z, Bahar H, Stasevych MV, Musyanovych R, Komarovska-Porokhnyavets O, Novikov VP (2011) Synthesis and biological evaluation of novel nitrogen- and sulfurcontaining hetero-1,4-naphthoquinones as potent antifungal and antibacterial agents. Eur $\mathrm{J}$ Med Chem 46:58615867

19. Beemelmanns C, Guo H, Rischer M, Poulsen M (2016) Natural products from microbes associated with insects. Beilstein J Org Chem 12: $314-327$

20. Cipriani FA, Figueiredo MR, Soares GLG, Kaplan MAC (2012) Implicações químicas na sistemática e filogenia de Bignoniaceae. Quim Nova 35: 2125-2131

21. Errante G, La Motta G, Lagana C, Wittebolle V, Sarciron MÉ, Barret R (2006) Synthesis and evaluation of antifungal activity of naphthoquinone derivatives. Eur J Med Chem 41:773-778

22. Hongju L, Chong Y, Changqun L, Tingting Y, Zhigang S (2020) Naphthoquinone Derivatives with Anti-Inflammatory Activity from Mangrove-Derived Endophytic Fungus Talaromyces sp. SK-S009. Molecules. 25(3): 576

23. Opitz W, Pelster B, Fruchtmann R, Krupka U, Gauss W, Kiehne H, Oediger H (1986) 1,4-Naphthoquinone derivatives having anti-inflammatory action, U.S. Patent 4628062A

24. Sánchez-Calvo JM, Barbero GR, Guerrero-Vásquez G, Duran AG, Macías M, Rodríguez-Iglesias MA, Molinillo JMG, Macías FA (2016) Synthesis, antibacterial and antifungal activities of naphthoquinone derivatives: a structure-activity relationship study. Med Chem Res 25:1274-1285

25. Wellington KW, Kolesnikova NI (2012) A laccase-catalysed one-pot synthesis of aminonaphthoquinones and their anticancer activity. Bioorg Med Chem 20: $4472-4481$

26. Ghosh SK, Ganta A, Spanjaard RA (2018) Discovery and cellular stress pathway analysis of 1,4-naphthoquinone derivatives with novel, highly potent broad-spectrum anticancer activity. J Biomed Sci. 2018 25:12

27. Matsumoto K, Choshi T, Hourai M, Zamami Y, Sasaki K, Abe T, Ishikura M, Hatae N, Iwamura T, Tohyama S, Nobuhiro J, Hibino S (2012) Synthesis and antimalarial activity of calothrixins $\mathrm{A}$ and $\mathrm{B}$, and their N-alkyl derivatives. Bioorg Med Chem Lett 22:4762-4764

28. Berghot MA, Kandeel EM, Abdel-Rahman AH and Marwa Abdel-Motaal (2014) Synthesis, Antioxidant and Cytotoxic Activities of Novel Naphthoquinone Derivatives from 2,3-Dihydro-2,3-Epoxy-1,4- Naphthoquinone. Med chem 2014, 4: 381-388

29. Deniz NG, Ibis C, Gokmen Z, Stasevych M, Novikov V, Komurovska-Porokhnyavets O, Ozyurek M, Guclu K, Karakas D, Ulukaya E (2015) Design, Synthesis, Biological Evaluation, and Antioxidant and Cytotoxic Activity of Heteroatom-substituted 1,4-Naphtho- and Benzoquinones. Chem Pharm Bull 63:10291039

30. Shivarama Holla B, Sooryanarayana Rao B, Shridhara K, Akberali PM (2000) Studies on arylfuran derivatives: part XI. Synthesis, characterisation and biological studies on some Mannich bases carrying 2,4-dichlorophenylfurfural moiety. Farmaco 55: 338-344

31. Chandramouli C, Shivanand MR, Nayanbhai TB, Bheemachari B, Udupi RH (2012) Synthesis and biological screening of certain new triazole schiff bases and their derivatives bearing substituted benzothiazole moiety. J Chem Pharm Res 4:1151-1159

32. Matar SA, Talib WH, Mustafa MS, Mubarak MS, AIDamen MA (2015) Synthesis, characterization, and antimicrobial activity of Schiff bases derived from benzaldehydes and 3,3'-diaminodipropylamine. Arab J Chem 8:850-857

33. Uddin N, Rashid F, Ali S, Tirmizi SA, Ahmad I, Zaib S, Zubir M, Diaconescu PL, Tahir MN, Iqbal J, Haider A (2019) Synthesis, characterization, and anticancer activity of Schiff bases. J Biomol Struct Dyn (2019) 38:3246-3259

34. Sivakumar KK, Rajasekaran A (2013) Synthesis, in-vitro antimicrobial and antitubercular screening of Schiff bases of 3-amino-1-phenyl-4- [2-(4-phenyl-1,3thiazol-2-yl) hydrazin-1-ylidene]-4,5-dihydro-1H-pyrazol-5-one. J Pharm Bioallied Sci. 5:126-135

35. Alafeefy AM, Bakht MA, Ganaie MA, Ansarie MN, El-Sayed NN, Awaad AS (2015) Synthesis, analgesic, anti-inflammatory and anti-ulcerogenic activities of certain novel Schiff's bases as fenamate isosteres. Bioorg Med Chem Lett. 25:179-183

36. Sharma V, Chitranshi N, Agarwal AK (2014) Significance and biological importance of pyrimidine in the microbial world. Int J Med Chem e202784

37. Elkanzi NAA, Hrichi H (2020) Design and Evaluation of Antimicrobial Activity of New Pyrazole, 1,2,4-Triazole, and 1,3,4-Thiadiazol Derivatives Bearing 1,4Dihydroquinoxaline Moiety. Russ J Bioorg Chem 46: 715-725

38. Elkanzi NAA, Hrichi H (2019) Green Synthesis, Characterization and Biological Evaluation of New Pyrazino Pyrido Quinolone Derivatives under Catalyst free Conditions. J Appl Chem 8: 26-37

Page 12/15 
39. Elkanzi NAA, Hrichi H (2020) Design and Evaluation of Antimicrobial Activity of New Pyrazole, 1,2,4-Triazole, and 1,3,4-Thiadiazol Derivatives Bearing 1,4Dihydroquinoxaline Moiety. Russ J Bioorg Chem 46:715-725

40. Gomaa MM (2014) Oxonium heterocyclic quinone in the synthesis of some cyanine dyes and their antimicrobial activity. Eur J Chem 5:463-468

41. Soleiman, HA, Koraiem Al, Mohmoud NY (2005) Synthesis of 3-Substituted Benzpyrid-4-imino-2-oxime Derivatives. J Chin Chem Soc 52:119-124

42. Gomaa M.M., El-Deen N.S., ElKanzi N.A.A. (2012) Benzo[g]quinoline heterocyclic derivative as a typical precursor in the synthesis of new class of cyaninelike dyes. Eur J Chem 3: 461-466

43. Hammer KA, Carson CF, Riley TV (1996) Susceptibility of transient and commensal skin flora to the essential oil of Melaleuca alternifolia (tea tree oil). Am $\mathrm{J}$ Infect Control 24:186-189

44. Panteleon V, Kostakis IK, Marakos P, Pouli N, Andreadou I (2008) Synthesis and free radical scavenging activity of some new spiropyranocoumarins. Bioorg Med Chem Lett 18:5781-5784

45. Isupov MN, Obmolova G, Butterworth S, Badet-Denisot MA, Badet B, Polikarpov I, Littlechild JA, Teplyakov A (1996) Substrate binding is required for assembly of the active conformation of the catalytic site in ntn amidotransferases: evidence from the 1.8 angstrom crystal structure of the glutaminase domain of glucosamine 6-phosphate synthase. Structure 4:801-810

46. Erlenmeyer H, Ueberwasser H (1942) Über isostere und strukturähnliche Verbindungen XVI. Zur Kenntnis des 4-Oxy-benzthiazols. Helv Chim Acta 25: 515521

47. Osman H, Arshad A, Kit Lam C, Bagley MC (2012) Microwaveassisted synthesis and antioxidant properties of hydrazinyl thiazolyl coumarin derivatives. Chem Cent J 6: 1-10

48. Kumagai Y, Shinkai Y, Miura T, Cho AK (2012) The chemical biology of naphthoquinones and its environmental implications. Annu Rev Pharmacol Toxicol $52: 221-247$

49. Santos-Sánchez NF, Salas-Coronado R, Villanueva-Cañongo C, Hernández-Carlos B (2019) Antioxidant compounds and their antioxidant mechanism. In Book Antioxidants, Shalaby E, Ed, IntechOpen: London, UK 1-28, ISBN 978-3-642-22646-5

50. Ilyasov IR, Beloborodov VL, Selivanova IA, Terekhov RP (2020) ABTS/PP decolorization assay of antioxidant capacity reaction pathways. Int J Mol Sci 21:1131

51. Uddin SN, Ali ME, Yesmin MN (2008) Antioxidant and antibacterial activities of Senna tora Roxb. Am J Plant Physiol 3: 96-100

52. Sharma OP, Bhata TK (2009) DPPH antioxidant assay revisited. Food Chem 113:1202-1205

53. Abdel-Rehim SS, Magdy AM Ibrahim, Khaled KF (1999) 4-Aminoantipyrine as an Inhibitor of mild Steel Corrosion in HCl Solution. J Applied Electrochemistry 29:593-59

54. Bakr RB,Elkanzi NAA (2020) Preparation of some novel thiazolidinones, imidazolinones, and azetidinone bearing pyridine and pyrimidine moieties with antimicrobial activity. J Heterocycl Chem 57:2977-2989

55. Vijesh A, Isloor AM, Telkar S, Arulmoli T, Fun HK (2013) Molecular docking studies of some new imidazole derivatives for antimicrobial properties. Arab J Chem 6:197-204

56. Elkanzi NAA, Bakr RB (2020) Microwave Assisted, Antimicrobial Activity and Molecular Modeling of Some Synthesized Newly Pyrimidine Derivatives Using 1, 4- diazabicyclo[2.2.2]octane as a Catalyst. Lett Drug Des Discov17:1538-1551

\section{Figures}

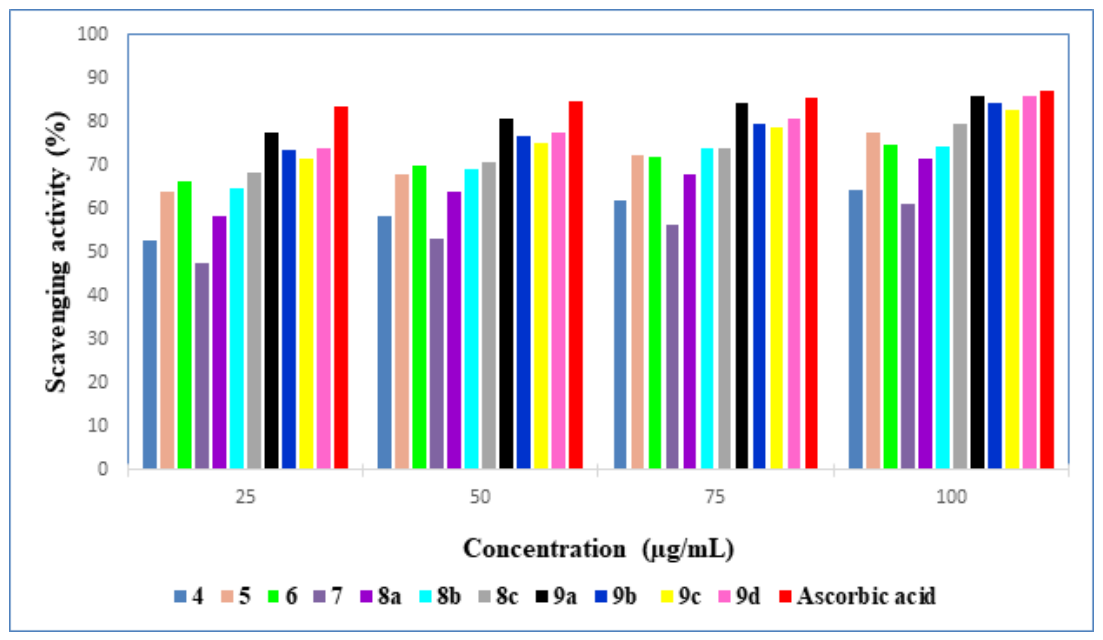

Figure 1

The proposed binding interactions between compound 9c and GlcN-6-P, A) 2D interactions B) 3D interactions. 


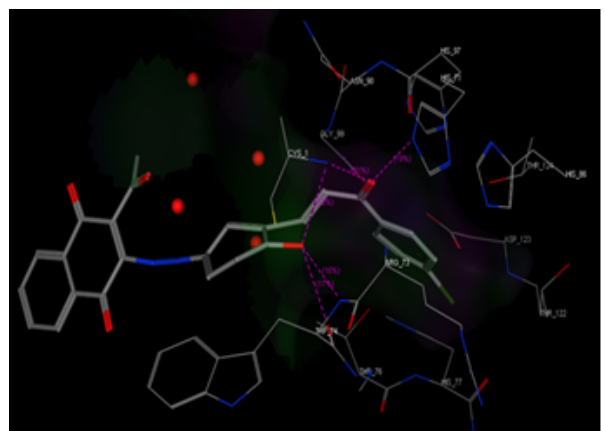

(A)

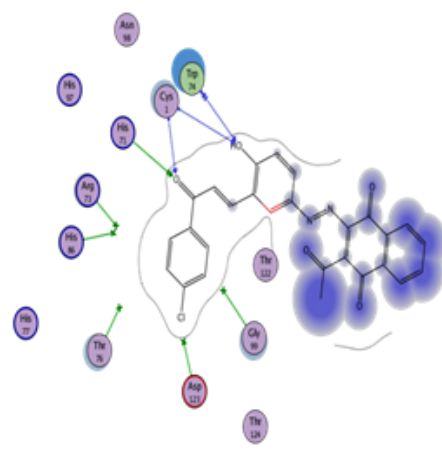

(B)

Figure 2

The proposed binding interactions between compound 9b and GlcN-6-P, A) 2D interactions B) 3D interactions.

(-)

(12)

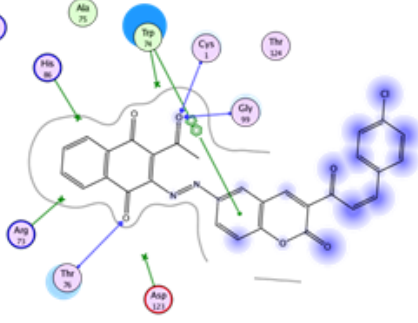

(-)

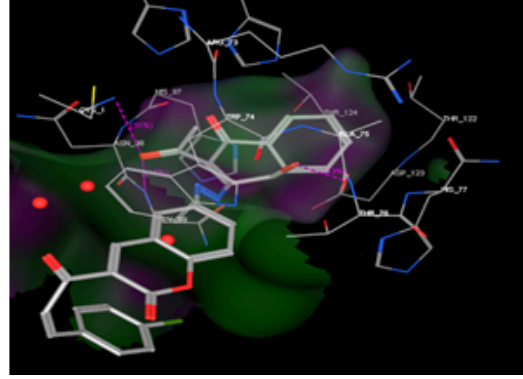

Figure 3

The proposed binding interactions between compound 8b and GlcN-6-P, A) 2D interactions B) 3D interactions.
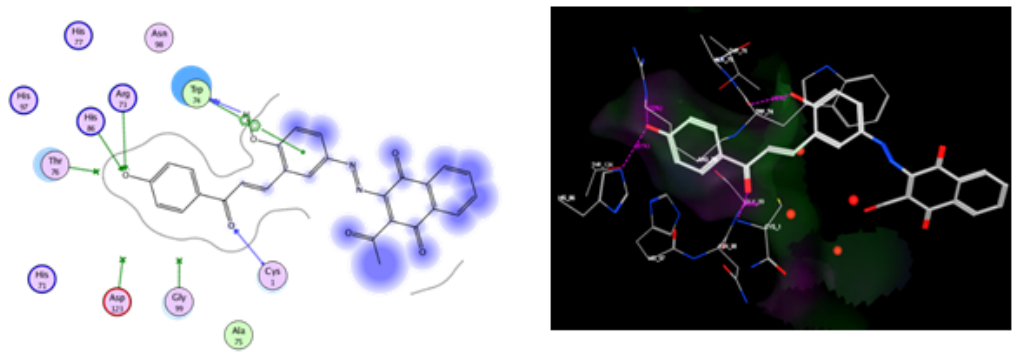

Figure 4

The proposed binding interactions between compound 9d and GlcN-6-P, A) 2D interactions B) 3D interactions.
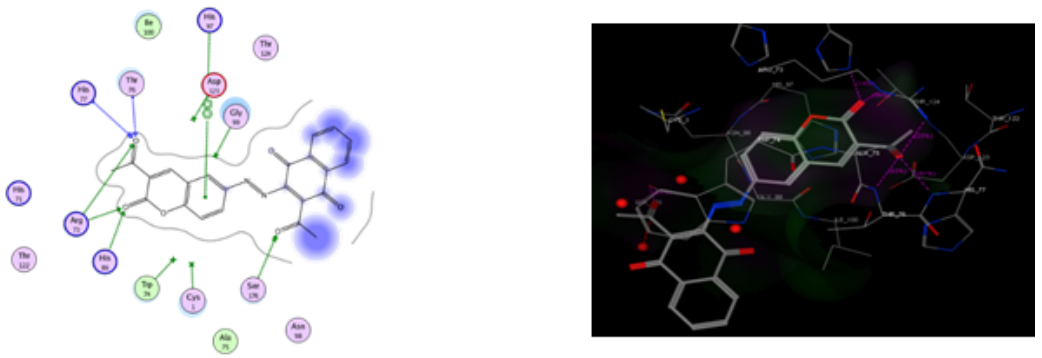

\section{Figure 5}

The proposed binding interactions between compound 7 and GlcN-6-P, A) 2D interactions B) 3D interactions.

\section{Supplementary Files}

This is a list of supplementary files associated with this preprint. Click to download. 
- Scheme02.png

- Scheme03.png

Page 15/15 